\title{
Analysis of Higyene Food Sanitation in Public Hospital in Sultan Iskandar Muda Regency Nagan Raya
}

\author{
${ }^{1}$ Jun Musnadi Is, ${ }^{2}$ Liza Sartika, ${ }^{3}$ Zakiyuddin \\ ${ }^{1}$ Public Health Faculty, Teuku Umar University, Meulaboh, Indonesia, junmusnadi@utu.ac.id \\ ${ }^{2}$ Public Health Faculty, Teuku Umar University, Meulaboh, Indonesia, sartikaliza@gmail.com \\ ${ }^{3}$ Public Health Faculty, Teuku Umar University, Meulaboh, Indonesia, zakiyuddin@utu.ac.id \\ Corespondingauthor : Jun Musnadi Is, e-mail : junmusnadi@utu.ac.id
}

\begin{abstract}
Introduction on food sanitation hygiene is an effort to control the factors of food, people, places and equipment that can or may cause illness or health problems. The purpose of this research is to find out how the Analysis of Food Sanitation Hygiene at Sultan Iskandar Muda Regional General Hospital, Nagan Raya Regency. This research is a qualitative study conducted at Sultan Iskandar Muda Regional General Hospital, Nagan Raya Regency, when the research was conducted in January 2019. Research informants as many as 12 people namely, 9 food handlers, 1 program implementer, and 2 patients, taken by purposive sampling. The results showed the overall results of food sanitation hygiene, especially in the room, were quite good because they had storage, cooking and serving food, but still had water deposits because they did not have slope / slope so the floor was slippery, infrastructure was inadequate because of the aids used, PPE that has not been well used, the food is counted pretty good because the storage is separate but certainly not contaminated because the food served is sometimes in direct contact with hands, and HR food handlers are inadequate because each sift consists of three people who process, serve and deliver food. Conclusion sanitation hygiene has been counted as good, however it is necessary to make improvements to be declared good overall. It is recommended to the officers in charge of the hospital to pay more attention to sanitary hygiene, both food and others.
\end{abstract}

\section{ARTICLE INFORMATION}

Submitted: $17 / 01 / 2020$

Revised: $15 / 02 / 2020$

Accepted: 21/04/2020

Published Online : 15/05/2020

Keywords:

Room

Infrastructure

Food

Human Resources

How to cite this article:. Is, J.M., Sartika, L., Zakiyuddin, Z. (2020). Analysis of Higyene Food Sanitation in Public Hospital in Sultan Iskandar Muda Regency Nagan Raya. JNS : Journal of Nutrition Science, 1(1), 22-27.

\section{Introduction}

Food hygiene is needed to protect food from contamination or infectious microorganisms. Nutrition services in hospitals are supporting health services that have the task of supporting patients' healing efforts in the shortest time possible. Foods that meet nutritional needs and are consumed will expedite healing and shorten the day of hospitalization. Providing hygienic and healthy food is the basic principle of managing food in hospitals because hospital food services are intended for the sick with the threat of spreading pathogenic germs. Foods that are not managed properly and correctly by food handlers can have negative impacts such as diseases and poisoning due to chemicals, microorganisms, plants or animals, and can also cause allergies. (RI Ministry of Health, 2013).

According to Serambinews (2015), there were problems with hundreds of patients starving since three days due to the lack of food supply from the hospital and (2017) found problems such as the discovery of caterpillars when patients eat breakfast and patients eat packaged rice because the cook of RSUD Nagan Raya went on strike. So that the health resulting from incompatible hygiene standards for food sanitation can have an impact on health in the 
form of food poisoning such as nausea, stomach ache, diarrhea, fever / chills, decreased appetite, and body weakness. Obtained the results of information from 1 program implementer that still found many problems due to food hygiene hygiene Sultan Iskandar Muda Regional Hospital district. Nagan Raya, which is a presenter, cooking, storage (dry, cold) room should be separated according to the standard, but from the staff themselves it is not done correctly and appropriately, the waiter is in direct contact with food because of incomplete protection (only using aprons and masks) against contamination, for washing places there is nothing special and the construction is still not hygienic because it is not in accordance with predetermined standards.

From the introduction above, the researcher is very interested in conducting research on "Analysis of Hygiene at Sultan Iskandar Muda Regional Hospital, Nagan Raya Regency".

In essence "Hygiene" and "Sanitation" have almost the same understanding and purpose of achieving excellent health. In law NUMBER 1096 / MENKES / PER / VI / 2011 Sanitation hygiene is an effort to control risk factors for food contamination, both from foodstuffs, people, places and equipment to be safe for consumption (Ministry of Health, 2011). Sudira (in Rachman, 2010) stated that: "Hygiene is health science and prevention of disease. Hygiene is more about the problem of bacteria as a cause of disease, while sanitation is more concerned with hygiene problems to achieve health".

\section{Method}

The design of this study is a type of qualitative research using purposive sampling which is a research method conducted by (Notoatmodjo, 2010). To find out hygiene hygiene analysis at Sultan Iskandar Muda General Hospital, Nagan Raya Regency. The location of this research was carried out at Sultan Iskandar Muda Regional General Hospital. This research was carried out in February 2019. There were 12 informants chosen by the researchers consisting of 1 key informant, 9 main informants and 2 supporting / additional informants.

\section{Results}

The Hospital of Sultan Iskandar Muda the development of the Ujong Fatihah care pukesmas and in 2004 the central government through the Ministry of Health allocated the 2004 state budget funds to build a polyclinic and administration and from the aceh 2004 provincial state budget to build the emergency room, the polyclinic and administration building had been built while the polyclinic building was delayed due to the earthquake and tsunami disaster at the end of 2004. After the earthquake and tsunami, the Nagan Raya district's earthquake and tsunami health service center was at the Puskesmas Puskesmas Ujong patihah (a child of the Sultan Iskandar Muda Hospital). On April 20, 2005 a decree was issued from the regent of Nagan Raya number 445/18/2005 regarding services at the Puskesmas Ujong Patihan nurses to become the health service office of the Sultan Iskandar Muda Hospital.

\section{Food Hygiene in the Room in the Nutrition Installation}

From the results of research at the RSUD on room standard questions obtained interviews results that: "if that (room standard) we do not know, because they are not experts they might know". (Main Informant 1). It can be seen from the observation and interview results that the nutrition installation room has changed slightly, because from the observation results it can be seen that the installation room has been separated from the storage, cooking and serving space, but it can also be seen that the room still has a pool of water, apart from that the results of the interviewer do not yet know the room standards at the RSUD.

\section{Higyene Food Sanitation in Facilities and Infrastructure in the Nutrition Installation.}

From the results of research at the RSUD on the question of PPE usage, it was obtained from interviews that: "Yes, for our own deck, if we wear a mask, if we sneeze, we don't fly (saliva) like that, if you wear an apron, don't get dirty, right? the gloves are called food by hand. "(Main Informant 7). In addition, from the results of research on the equipment questions used, the results are obtained: "Trolley, that's the trolley that has broken the door. In the past two pieces now only one has broken the door." (Main Informant 4). From the results of observations and interviews about infrastructure suggestions, we can conclude that the facilities and infrastructure at the public hospital are already aware of the use of PPE. Others also do not know the benefits of PPE used. The tools used at the Regional Hospital also cannot function properly because they are damaged.

\section{Food Hygiene Hygiene in Food In Nutrition Installation at Sultan Iskandar Muda District Hospital, Nagan Raya Regency}


on food ingredients there are questions about food storage arrangements between wet food and dry food, the results can be found, namely: "If that (temperature regulation) we don't know, it's not because the one who controls nutrition is the nutritional person who always controls" (Main Informant 5). In addition to the question about food storage and processing procedures we can see based on the answer: "We wash the food first like that, first wash it after it is cut after being washed, washed once more then cooked, according to the menu. That person is deck who knows we left when cooking ingredients were already there. (Main Informant 4). For the question of the requirements for officers in processing food, it is obtained: "The requirements are to use equipment like an apron, a mask like that when you want to cook. Yes, how to wash hand "(Main Informant 5). And in the food processing technique, it was found that the answers were: "Different decks, different TBs, different DMs, if we use $T B$, we use boxes if we reduce salt like that" (Main Informant 5). And for the question of how to find out which cuisine is delicious / fit and the presentation schedule, the results of the interview are: "We think we used the spoon first. Morning at 00.06 if noon at 12.00 at night at 05.00 "(Main Informant $3)$.

From the results of observations and questions on the informant it can be concluded that for food storage procedures the catering services do not yet know how the procedure is, the processing requirements are known but only the full application is done. For the treatment of patients with certain diseases, RSUD does not yet have a hot water washer, the way they know the food they serve is right / tasty by tasting it, but there are also those who use their instincts and to schedule food serving is good, but only sometimes experience delays.

\section{Food Hygiene Hygiene at Human Resources at Nutrition Installation at Sultan Iskandar Muda Hospital, Nagan Raya Regency.}

On HR about the benefits of food handlers using PPE, the results show that: "we once deck, there is no substitute" (Main Informant5). "Twice, noon and noon in the same afternoon" (Main Informant1). For the question if there is a friend who suffers from pain, how can the action be taken to overcome the interview: "Yes, if it is not severe, we tell you to wear a mask, yes, we say also check it badly or not, if you just get some rest, don't work like that" (Main Informant 5). Next to the HR standard questions on nutrition installations, the results were obtained; "Not yet deck, we only have three, which might be enough, if one person does not enter the permit, there are only two left, it's difficult to work" (Main Informant3). On the question of whether there is a health education and counseling, the results are obtained: "Yes, there is a saying that this should not be a lot this time, like for example the $T B$ disease uses such a box. There's a tip every month there. Certificates, eum yes there is no certificate brother deck"(Main Informant9).

From the results of observations and interviews also obtained the results of research that HR in hospitals is not sufficient and there are also a number of services that do not change clothes and only rely on aprons when working because of the reason they live far away. And for counseling and health checks is good because food handlers always get counseling, once six months now once a month.

And based on the community's view, the results of the facilities and infrastructure "do not know, it is appropriate that we say" from the answer, we can know that the infrastructure according to the community's view is good. In addition to the next question about food according to community opinion "varied, different", from that answer we can know that the food served is varied and the menus are different.

According to the nutrition executive about the room "eummmm ... the room is already good, we can see for ourselves how, compared to what was already good yesterday". From the answers above it can be concluded that the space in the installation is adequate but the procurement is not perfect because the hospital floor can be seen clearly that there are a lot of water deposits caused by the floor not having a slope which can cause the floor to be slippery.

Regarding the facilities and infrastructure of the program implementer, it said that "there are still many things that are lacking, it should be about hot water washing, already, proposing but not yet available, but the only solution is that there is no hot water washing for infectious patients, namely by presenting boxes, yes rice boxes what is it ?, the place doesn't exist according to the room, it's not yet adequate From the answers of the program implementers we can conclude that the hospital does not yet have adequate facilities and infrastructure where the hospital does not yet have a hot water washer so they use boxes for patients suffering from TB.

In the foodstuffs, interviews were obtained from program implementers, namely: "Here there is a third party, so when the ordered goods are ordered, there is 
an order paper like Mrs. Menoe (with the mother earlier), it was given to the partners of Menoe (earlier) who worked at the hospital so come food is received by the nutrition officer in the morning at 08.00 , every time a new betol is checked again, there is a third party partner who has worked with the hospital. Yes, here from intersection four, there are too those who receive food right, in collaboration with the hospital, the nutritionist ordered it. That is the treasurer's business, not related to us, it is the same as the top people, so they are just, for example, the number today is like this, made, I have been asked to make it, oh, don't you think so, yeah, every month there are one hundred more like that, there are under one hundred according to those ordered by nutritionists, nutritionists order according to their orders, according to patients. Eumm. Spatial nutritionist, there is an aesthetic diet with a nutritionist, oh yes this patient DM and this, washed with a cooking person, a cooking person cooks it by looking at a nutritionist's diet book, yes and a diet that has been in the room of a nutritionist, to write a diet book this-this-this diet, washed with the cook. " From the results of the interview we can conclude that the program implementers did not know the origin of the foodstuffs processed by food handlers, they only recapitulated after the food came in the nutrition installation room.

In the HR question for program implementers the answer was obtained that "the cooks were not enough. Yes, than before it was pretty decent. " From these results we can know that the human resources of food handlers in the installation are inadequate. We can see where in one shift there are three food handlers, where the three handlers do the processing, serving and delivery of food to patients in the Sultan Iskandar Muda hospital.

From these results we can conclude that the room in a nutrition installation was found that the hospital room was fairly good but not yet adequate, we can see on the floor that there was water deposition because the floor did not have a slope / loneliness so this could cause the floor to be slippery. The facilities and infrastructure are also inadequate, this is due to the absence of hot water washing so for TB they use boxes. In food ingredients, the executors did not go down directly to sort food ingredients because the food had been ordered by the hospital partners and the hospital's human resources were inadequate because there were only three food handlers in one shift. It is these three people who process, serve and deliver food to patients so that it sometimes results in delays in delivering food to patients.

\section{Discussion}

The reseach result of qualitative study analysis we can examine that as follows:

\section{Higyene Food Sanitation in the Room at the Nutrition Installation at Sultan Iskandar Muda Hospital, Nagan Raya Regency.}

Based on the results of research in the general hospital room of the young Sultan Iskandar area from observations at the hospital, it can be found that the food storage room, cooking room and food serving room are separated and can be said to be appropriate but for the floor in the cooking and washing room experiencing water deposits caused by the floor does not have a slope or slope so that it can cause the floor slippery.

Food Hygiene Hygiene at Human Resources at Nutrition Installation at Sultan Iskandar Muda Hospital, Nagan Raya Regency.

Based on the results of research on the facilities and infrastructure of general hospitals in the area of general hospitals is inadequate, we can see trolleys and hot water washers in hospitals as yet. In addition, the organizer said that the facilities at the hospital were not good or did not meet the standards but were better than the previous year.

Food Hygiene Hygiene at Human Resources in Nutrition Installation at Sultan Iskandar Muda Hospital, Nagan Raya Regency.

Based on the results of food research in the general hospital of the Sultan Iskandar Muda area, it was observed that the installation room has a separate storage, processing and presentation room besides that in the storage room we can see that for storing dry and wet materials are also separate. For dry foodstuffs, it is placed in a designated room and the shelves used for dry foodstuffs have a distance between foodstuffs and the floor. Wet foodstuffs are placed in rooms that have cold temperatures. In the procurement of foodstuffs, the handlers and the implementation of the program do not know the origin of the food in the hospital

Food Hygiene Hygiene at Human Resources at Nutrition Installation at Sultan Iskandar Muda Hospital, Nagan Raya Regency.

Based on the results of HR research at the Sultan Iskandar Muda Regional General Hospital, it 
has not been fulfilled properly, it can be clearly seen that the existing HR is inadequate because there are only 9 food handlers and divided into three shifts, one shift consists of 3 people. Those 3 handlers do the processing, serving and delivery of food to the patient, causing delays in the delivery of food to the patient from the program implementer, and they are informed that the handler's paea is inadequate or insufficient but rather than before. In addition, the officials also said that they lacked people because there were only 3 people who worked every shift if one of them was sick or there was no substitute for permission so that sometimes they experienced delays when delivering food.

\section{Conclusion}

Based on research results obtained from observations, namely:

1. Food storage space, cooking room and food serving room are limited but on the hospital floor complicated air deposits that cause the floor to have no slope or slope so the floor becomes slippery.

2. Inadequate facilities and infrastructure, can be seen from trolleys and hot air washers that do not yet exist, the executive also said that the facilities at the hospital were not good or did not meet the hospital facility standards were better than last year.

3. Even food handlers and program organizers do not know the origin of the food in the hospital other than that the food carrier for the patient is not enough because one of the tools used in the damage. The serving area in the hospital is quite good because for other diseases, we have to use a place to eat, but for TB patients, they still use the box related to the hot air washer.

4. Human resources have not been fulfilled properly, as a whole it can be seen that the existing human resources do not meet the food handlers only consist of 9 people and are divided into three shifts. One shift consists of 3 people. 3 people made the preparation, presentation and delivery of food to the patient, causing delays in the delivery of food to the patient. The implementers also said that food handlers were still inadequate or tolerable from before. From the handlers also obtained information about those who lack people each shift consists of 3 people and if one of them is sick or sudden permission there is another substitute to make it possible to reduce delays in food delivery.

\section{Acknowledgement}

Acknowledgments, researchers presented to the Rector of Teuku Umar University, Research Institute, Community Service, and Quality Assurance of Teuku Umar University, Dean of the Publich Health Faculty-Teuku Umar University, Geuchik Village of KampungBelakang, Village Apparatus of KampungBelakang Village, all respondents who were residents of KampungBelakang Village , the fiber of student of Publich Health Faculty who have contributed a lot so that this research can run well and be able to be written in journal form.

\section{Author Contribution and Competing Interest}

Author contribution in this research are involved in the design of research project, collecting data or analyzing result, involved in drafting or revising scientific papers.

\section{Publisher's Note}

JONS : Jurnal Of Nutritien Scienceremains neutral with regard to jurisdictional claims in published institutional affilition.

\section{References}

Anonim, 2014. Kamus gizi perlengkapan kesehatan keluarga. Penerbit buku kompas. Jakarta

Anwar dkk . 2011. Bidang studi makanan dan minuman pada instalasi tenaga sanitasi. Bandung

Aswar. 2011. Sikap manusia dan teori pengukurannya. Pustaka: Yogyakarta

Atun. R. 2016. Faktor-faktor yang mempengaruhi personal hygiene penjamah makanan di kantin universitas esa unggul tahun 2016. http://digilib.esaunggul.ac.id/public/UEU-

Undergraduate-8203 JURNAL.pdf - diakses Mei 2018.

Burhan . 2011. Analisis data penelitian kualitatif. Jakarta: Raja bafindo persada

BPOM. 2013. Peraturan kepala badan pengawasan obat dan makanan republic Indonesia nomor 5 tahun 2015 tentang pedoman cara litel pangan yang baik dipasar tradisional. Jakarta. BPOM

Dewi Marheani, dkk. 2015. Analisis pelayanan gizi rumah sakit dengan pendekatan Healt Technologi Asseassement (HTA). Jurnal Kesehatan Masyarakat Vol.01 No.02

Emy Shinta, dkk. 2015. Analisis implementasi pelayanan gizi di RSUD Tugurejo Semarang. Jurnal Manajemen Kesehatan Indonesia Vol.03 No.02 
Fathonah. 2012. Higiene sanitasi makanan. UNNES Press. Semarang

Fauzie, M.M. dan Herawati, L., 2014. Pengaruh Penyuluhan terhadap Peningkatan Motivasi dan Tindakan dalam Mencuci tangan dan membuang sampah. Sanitasi jurnal kesehatan lingkungan, 5 (4) hal 151-158

FOODSAFE. (n.d.). Retrieved April 21, 2015, from http://www.foodsafe.ca

Food Safety Definitions for Food Vendors at Special Events. (n.d.). Retrieved April 22, 2015, from http://www.halton.ca/cms/one.aspx?portalId=8 310\&pageId $=37644$

Husaini dan Purnomo. 2010. Metode penelitian sosial . Jakarta: PT bumi aksara

Iqdhana Chantika, dkk. 2016. Higiene penjamah makanan dan sanitasi pengolahan makanan diinstalasi gizi Rumah Sakit Umum Daerah Gambira Kota Kendiri. Jurnal Preventia Vol.01 No.01

Kemenkes, 2011. Tentang hygiene dan sanitasi jasaboga. Nomor 1096/Menkes/PER/VI/2011.

Kemenkes, 2013. Pedoman Pelayanan Gizi Rumah Sakit (PGRS) . Jakarta: Dirjen Binkesmas.

Moeleong. 2011. Metodologi Penelitian Kualitatif, Bandung: Remaja Rosdakarya.

Mustika Putri, dkk. 2016. Penyelenggaraan makanan dan kepuasan konsumen dikantin lantai 2 rumah sakit universitas airlangga Surabaya. Jurnal Kesehatan Masyarakat vol.11 no. 01

Notoatmodjo, S. 2010. Metodologi Penelitian Kesehatan. Jakarta : Rineka Cipta.

Notoatmodjo, S 2013. Tujuan pengawasan kesalahan mencari umpan balik (feedback) yang memberikan pengarahan dan perbaikanperbaikan. Jakarta : Rineka Cipta

Oldriana Prawiro Haspari, dkk, 2018. Analisis Praktis Hygiene Sanitasi Karyawan Instalasi Gizi Studi Kasus Di Rumah Sakit Yogyakarta. Jurnal Medicoeticolegal Dan Manajemen Rumah Sakit, Vol.7 No.10

Okta Setyawati, dkk. 2015. higiene sanitasi jajan pasar Kotagede Yogyakarta. Jurnal Keluarga Vol.01 No.02

Rahimy. 2015. Manajemen pelayanan gizi rumah sakit. Yogyakarta : CV andi offset
Raras Putri, Dkk. 2016. Higiene sanitasi makanan diterminal penumpang pelabuhan tanjung emas semarang. Jurnal kesehatan masyarakat. Vol. 04. No. 01

Riski muliawardani. 2015. Analisis manajemen pelayanan gizi di rumah sakit jiwa Grhasia Daerah Istimewa Yogyakarta. Jurnal Kesehatan Masyarakat Vol.10 No.01

Sugiyono.(2016). MetodologiPenelitian Kuantitatif, Kualitatif, dan R\&D.In CV Alfabeta. https://doi.org/https://doi.org/10.3929/ethz-b000238666

Serambinews, 2015 dan 2017. Breaking News tentang Penemuan ulat,pasien makan nasi bungkus dan ratusan pasien kelaparan Di RSUD Sultan Iskandar Muda. https://aceh.tribunnews.com/2015 dan 2017.

Topowijono, 2018. Penerapan Hygiene Sanitasi Dalam Upaya Peningkatan Mutu Kualitas Food And Baverage Pada Pantai Indah Desa Ngelebeng Kecamatan Panggul Kabupaten Trenggalek. Jurnal Administrasi Vol.58 No.2

Victa Sonia, Dkk, 2013. Evaluasi Penerapan Hygiene Dan Sanitasi Penyelenggaraan Makanan Di RSUD Sunan Kalijaga Kabupaten Demak. Jurnal Kesehatan Masyarakat Vol.4 No.2

Vionil. L. dkk. 2018. Higiene sanitasi pengolahan makanan dan angka kuman peralatan makanan (piring) diinstalasi gizi Rumah Sakit Umum Pancara Kasih GMM kota Manado. Jurnal Kesehatan Masyarakat Vol.07 N0.05

WHO. 2015 .akses fasilitas sanitasi penduduk dunia yang masih jadi masalah dibelahan dunia. Yogyakarta: Pusat Pelajar. 